\title{
Digestion by pigs of non-starch polysaccharides in wheat and raw peas (Pisum sativum) fed in mixed diets
}

\author{
BY J.S. GOODLAD AND J. C. MATHERS* \\ Department of Agricultural Biochemistry and Nutrition, University of Newcastle upon Tyne, \\ Newcastle upon Tyne NE1 $7 R U$
}

(Received 21 June 1990 - Accepted 9 October 1990)

\begin{abstract}
The digestion by pigs of non-starch polysaccharides (NSP) in wheat and raw peas (Pisum sativum) fed in mixed diets was measured. In the four experimental diets, wheat was included at a constant $500 \mathrm{~g} / \mathrm{kg}$ whilst peas contributed $0-300 \mathrm{~g} / \mathrm{kg}$ and these were the only dietary sources of NSP. Separate estimates of digestibility for wheat and peas were obtained by using a multiple linear regression technique which also tested the possibility that the presence of peas might influence the digestibility of wheat NSP. There was little evidence of the latter and it was found that the digestibility of peas NSP (0.84) was considerably greater than that of wheat (0.65). The non-cellulosic polysaccharides (NCP) had twofold greater digestibilities than had cellulose for both foods with essentially all the peas NCP being digested. Faecal $\alpha, \varepsilon$-diaminopimelic acid concentration increased with feeding of peas, suggesting stimulation of bacterial biomass production in the large intestine using the readily fermented peas NSP. All three major volatile fatty acids produced by large intestinal fermentation were detected in jugular blood and increased significantly with increasing peas inclusion rate in the diet.
\end{abstract}

Non-starch polysaccharides: Peas: Wheat: Pig

Mature dry peas (Pisum sativum) are a rich source of oligosaccharides and polysaccharides, the latter including starches which are relatively slowly digested by pancreatic $\alpha$-amylase (EC 3.2.1.1) (Longstaff \& McNab, 1987) even after cooking (Würsch et al. 1986) and the cell-wall polysaccharides (non-starch polysaccharides; NSP) which contribute to the dietary fibre complex. NSP, oligosaccharides and that fraction of starch which is not digested by $\alpha$-amylase provide the majority of organic matter which flows to, and is fermented in, the large bowel (LB) (Cummings \& Englyst, 1987). In a previous study (Goodlad \& Mathers, 1990) in which raw peas were incorporated into semi-purified diets offered to rats, starch and oligosaccharides were not detected in faeces and it was assumed that these carbohydrate fractions were completely digested or fermented, or both. In addition, the apparent digestibility of peas NSP was high (0.79) at all levels of dietary inclusion $(100-500 \mathrm{~g}$ peas $/ \mathrm{kg})$. In adult cockerels, coefficients of digestion for starch and NSP from ground raw peas were considerably lower at $0.88-0.92$ and $0.31-0.44$ respectively (Longstaff \& $\mathrm{McNab}, 1987$ ). There is no comparable information for peas carbohydrate digestion by pigs which, because of their relatively larger LB and longer transit times, might be expected to be more effective in digesting those carbohydrate fractions which escape digestion in the small intestine.

The present study was designed to measure the digestibility of NSP and its constituent monosaccharides in raw peas fed to pigs. The peas were incorporated at graded levels into wheat-based diets such that wheat and peas provided the only complex carbohydrates and the contribution made by wheat remained constant. A multiple linear regression (MLR)

* For reprints. 
procedure was used to derive separate estimates of apparent digestibility for peas and wheat and to ascertain whether there was any interaction between these two foods in the extent of NSP digestion. Concentrations of volatile fatty acids (VFA) in jugular blood were measured as an indication of the potential for LB fermentation to influence metabolite supply to post-hepatic tissues (Pomare et al. 1985).

\section{MATERIALS AND METHODS}

\section{Animals and housing}

Twenty castrate male pigs (the progeny of Large White boars on F1 sows which were crosses between Large White, Duroc and Landrace animals), mean initial weight 29.9 (SE 0.91) kg were selected from the commercial herd at Cockle Park Farm (University of Newcastle upon Tyne) and housed in individual metabolism cages which allowed separation and complete collection of urine and faeces.

\section{Diets and feeding}

Four experimental diets, each containing $500 \mathrm{~g}$ milled wheat $/ \mathrm{kg}$ and graded concentrations $(0-300 \mathrm{~g} / \mathrm{kg})$ of milled raw peas (Pisum sativum var. Sentinel), were formulated to be of similar nitrogen and energy contents, as shown in Table 1 , with peas included at the expense of sucrose and fish meal. Wheat and peas were the only dietary sources of complex carbohydrates.

For the first $5 \mathrm{~d}$ whilst in metabolism cages, the pigs were fed on a complete commercial diet (Customix; Varley Feeds, Darlington). Over the next $3 \mathrm{~d}$ the pigs were gradually accustomed to the appropriate experimental diet by mixing it with the commercial diet in the proportions $1: 3,1: 1$ and $3: 1(\mathrm{w} / \mathrm{w})$ on days 6,7 and 8 respectively so that by day 9 of the study and, thereafter, each animal received the appropriate experimental diet only. Each animal was offered daily an amount $(\mathrm{kg})$ of air-dry food equivalent to $0 \cdot 1$ of the animal's metabolic body-weight, i.e. (body-weight) ${ }^{0.75}$. The ration was offered in two equal meals mixed into a slurry with 1 litre water at 09.00 and 16.00 hours daily. Access to the meal was permitted for $45 \mathrm{~min}$ after which any uneaten food was removed, oven-dried and weighed. Drinking water was available $a d l i b$.

\section{Experimental protocol}

After $7 \mathrm{~d}$ on the full experimental diet, the animals were weighed and a $7 \mathrm{~d}$ balance study carried out during which food intake was measured and all faeces and urine produced were collected. Faeces were collected daily and stored at $-20^{\circ}$ until required for analysis. Urine was collected into buckets containing $20 \mathrm{ml}$ aqueous sulphuric acid $(500 \mathrm{ml} / 1)$. The daily output from each animal was measured and a subsample $(50 \mathrm{ml} / \mathrm{l})$ stored at $4^{\circ}$. The pigs were reweighed at the end of the $7 \mathrm{~d}$ balance period and $10 \mathrm{ml}$ blood collected by jugular puncture into heparinized tubes and held on ice until storage at $-20^{\circ}$.

\section{Analytical methods}

Before analysis, frozen faeces from each animal were allowed to thaw, then bulked, mixed in a commercial dough mixer and a subsample taken for freeze-drying and subsequent milling. Diets and faeces were analysed for $\mathrm{N}$ by a Kjeldahl procedure and for gross energy using a Gallenkamp ballistic bomb calorimeter. For the latter analysis, urine was first freeze-dried. Determinations of NSP on diets and faeces were carried out by the method of Englyst \& Cummings (1984), and resistant starch was measured by omitting the dimethyl sulphoxide (DMSO) addition step. Oligosaccharides in the diets and faeces, $\alpha, \epsilon$ diaminopimelic acid (DAPA) in faeces and blood volatile fatty acids (VFA) were 
Table 1. Formulation $(\mathrm{g} / \mathrm{kg})$ and analysed composition $(\mathrm{g} / \mathrm{kg}$ dry matter $(D M))$ of the diets

\begin{tabular}{|c|c|c|c|c|}
\hline \multirow[b]{2}{*}{ Constituent } & \multicolumn{4}{|c|}{ Diet } \\
\hline & 1 & 2 & 3 & 4 \\
\hline Peas & 0 & 100 & 200 & 300 \\
\hline Wheat & 500 & 500 & 500 & 500 \\
\hline Fish meal & 205 & 170 & 135 & 100 \\
\hline Sucrose & 245 & 170 & 95 & 20 \\
\hline Maize oil & 0 & 10 & 20 & 30 \\
\hline Vitamin and mineral premix* & 50 & 50 & 50 & 50 \\
\hline \multicolumn{5}{|l|}{ Analysed composition ( $\mathrm{g} / \mathrm{kg} \mathrm{DM})$} \\
\hline Gross energy (MJ/kg DM) & $18 \cdot 0$ & $18 \cdot 9$ & $17 \cdot 6$ & $19 \cdot 5$ \\
\hline Nitrogen & $28 \cdot 1$ & $28 \cdot 4$ & $27 \cdot 5$ & $28 \cdot 5$ \\
\hline Total non-starch polysaccharides & $44 \cdot 2$ & $59 \cdot 7$ & $73 \cdot 1$ & $89 \cdot 7$ \\
\hline Cellulose & $7 \cdot 7$ & $14 \cdot 0$ & $17 \cdot 8$ & 21.9 \\
\hline Non-cellulosic polysaccharides & $36 \cdot 4$ & $45 \cdot 7$ & $55 \cdot 3$ & 67.6 \\
\hline Arabinose & $9 \cdot 5$ & $13 \cdot 6$ & $18 \cdot 1$ & $23 \cdot 1$ \\
\hline Xylose & $16 \cdot 7$ & $18 \cdot 6$ & $22 \cdot 0$ & 24.6 \\
\hline Mannose $\dagger$ & $0 \cdot 3$ & 0.4 & $0 \cdot 5$ & $0 \cdot 6$ \\
\hline Galactose & 0.9 & $2 \cdot 1$ & $2 \cdot 6$ & $3 \cdot 5$ \\
\hline Glucose & $16 \cdot 2$ & $22 \cdot 1$ & $27 \cdot 9$ & 37.6 \\
\hline Uronic acids & $1 \cdot 4$ & $4 \cdot 1$ & 499 & $5 \cdot 7$ \\
\hline Resistant starch & 11 & 14 & 31 & 54 \\
\hline Total oligosaccharides & 0 & $5 \cdot 1$ & $7 \cdot 5$ & $9 \cdot 5$ \\
\hline Raffinose & 0 & $1 \cdot 5$ & $1 \cdot 5$ & $2 \cdot 2$ \\
\hline Stachyose & 0 & $2 \cdot 2$ & $2 \cdot 6$ & 3.4 \\
\hline Verbascose & 0 & $1 \cdot 5$ & $3 \cdot 4$ & $4 \cdot 0$ \\
\hline
\end{tabular}

* Supplied by Unilever Research, Colworth House, Bedford.

$\uparrow$ Calculated from analysed composition of wheat and peas.

determined as described by Goodlad \& Mathers (1990). Blood glucose was assayed using a Yellow Springs Instruments (Yellow Springs, Ohio 45387, USA) model 23A glucose analyser.

\section{Experimental design and statistical analysis}

The experiment was designed as a single factor study with four treatments (diets) and five replicates (pigs) per diet. Values were examined by one-way analysis of variance and orthogonal polymonials were used to describe responses to peas inclusion in the diets. Results are presented as means for each diet with their standard errors based on the between-animals within-diets variation with $16 \mathrm{df}$. Separate estimates of apparent digestibility of wheat and of peas polysaccharides were obtained by an MLR technique outlined by Key \& Mathers (1990); a similar approach was adopted by Van Dokkum et al. (1983) to obtain estimates of the digestibility of fibre in breads added to a basal diet. In the present study, two MLR models were used:

MLR model 1: $Y=\alpha_{1} X_{1}+\alpha_{2} X_{2}+\alpha_{3} X_{1} X_{3}$,

where $Y$ was output of NSP in the faeces, $X_{1}$ and $X_{2}$ were intakes of NSP from wheat and peas respectively, $X_{3}$ has the value of 0 or 1 when peas were absent from or present in the diet respectively, $\alpha_{1}$ and $\alpha_{2}$ are the coefficients of indigestibilities for NSP in wheat and peas respectively and $\alpha_{3}$ is the additional effect of presence of peas on wheat NSP indigestibility. Where $\alpha_{3}$ is non-significant, a simpler model is appropriate:

MLR model 2: $Y=\beta_{1} X_{1}+\beta_{2} X_{2}$, 
where $\beta_{1}$ and $\beta_{2}$ are the coefficients of indigestibility for wheat and peas NSP respectively. Computations were carried out using the Statgraphics package (STSC Inc., Rocksville, Maryland, USA). Apparent digestibilities were calculated by subtracting the appropriate coefficients of indigestibility from unity.

\section{RESULTS}

\section{Diet composition}

Gross energy (GE) and $\mathrm{N}$ contents of the diets were similar as intended, whilst the concentration of NSP increased twofold as the proportion of peas in the diet increased. Where wheat was the only complex carbohydrate source (diet 1), glucose and xylose were the major NSP constituent sugars with smaller contributions from arabinose and uronic acids. As the peas inclusion rate increased, arabinose, uronic acids and galactose made relatively greater contributions whilst mannose was quantitatively unimportant in all diets. The concentration of starch resistant to $\alpha$-amylase in vitro without previous treatment with DMSO (resistant starch) increased fivefold from the lowest to highest peas inclusion rate. The oligosaccharides raffinose, stachyose and verbascose were not detected in diet 1 (zero peas) but contributed nearly $10 \mathrm{~g} / \mathrm{kg}$ to the highest peas-containing diet (Table 1 ).

\section{Animal well-being and growth}

Two pigs scoured after being transferred to the metabolism cages and were replaced by two others. All animals consumed all the allocated food during the experimental period and there was no evidence of any adverse effect of the diets. The slightly lower dry matter (DM) intakes for animals on the higher-peas diets were due to the slightly lower DM concentration in these diets and to slightly smaller pigs being randomly allocated to these diets. Growth rates were high and food conversion ratios were low and similar for all diets. There were no significant effects of diet on any measure of $\mathrm{N}$ metabolism (Table 2).

\section{Faecal DM and GE}

Output of wet faeces and of faecal DM tended to increase whilst apparent DM digestibility decreased with increasing dietary peas inclusion rate, but none of these dietary effects was statistically significant $(P>0.05$; Table 3$)$. There was a significant $(P<0.01)$ linear increase in the GE content of faecal DM as peas inclusion rate increased which resulted in a linear increase $(P<0.05)$ in faecal GE output and a linear $(P<0.05)$ decrease in apparent GE digestibility. Urinary GE output was not significantly $(P>0.05)$ affected by diet (Table 3 ) as would be expected from the lack of effect on urinary $\mathbf{N}$ output (Table 2).

\section{Apparent digestibility of NSP}

Including peas in the diet resulted in significant linear increases in the apparent digestibilities of dietary NSP, of non-cellulosic polysaccharides (NCP) and of the NSP constituent sugars arabinose, galactose and uronic acids, and non-significant increases for the other constituents cellulose, xylose, mannose and glucose (Table 4). For galactose and uronic acids, apparent digestibility was considerably higher and similar with the three peascontaining diets compared with the basal (zero peas) diet. It should be noted that the analysed contents of galactose and uronic acids in the diets (Table 1) did not show the expected regular increase with increasing peas inclusion rate. Any errors in diet analysis will tend to reduce the linearity in response in digestibility to increasing dietary peas content and may account for the deviations in linearity observed for galactose and uronic acids. Cellulose was less well digested than NCP in all diets but especially in the basal (zero peas) 
Table 2. Dry matter (DM) intake, growth performance and nitrogen metabolism in pigs given wheat-based diets containing graded amounts of raw peas (Pisum sativum var. Sentinel $) \dagger$

(Means for five pigs per diet)

\begin{tabular}{|c|c|c|c|c|c|c|}
\hline & \multicolumn{4}{|c|}{ Peas in diet $(\mathrm{g} / \mathrm{kg})$} & \multirow{2}{*}{$\begin{array}{l}\mathrm{SE} \text { of } \\
\text { mean }\end{array}$} & \multirow{2}{*}{$\begin{array}{l}\text { Statistical significance of } \\
\text { linear effect of dietary peas } \\
\text { inclusion rate }\end{array}$} \\
\hline & 0 & 100 & 200 & 300 & & \\
\hline DM intake $(\mathrm{kg} / 7 \mathrm{~d})$ & $9 \cdot 02$ & $9 \cdot 06$ & 8.72 & $8 \cdot 75$ & $0 \cdot 111$ & $*$ \\
\hline Growth rate $(\mathrm{kg} / 7 \mathrm{~d})$ & $5 \cdot 10$ & $5 \cdot 05$ & 4.91 & $5 \cdot 32$ & 0.539 & NS \\
\hline FCR & $1 \cdot 80$ & $1 \cdot 88$ & 1.88 & $1 \cdot 71$ & $0 \cdot 182$ & NS \\
\hline $\mathrm{N}$ intake $(\mathrm{g} / 7 \mathrm{~d})$ & 253 & 257 & 239 & 249 & $3 \cdot 2$ & NS \\
\hline Faecal $N$ output $(\mathrm{g} / 7 \mathrm{~d})$ & 31 & 33 & 35 & 34 & $3 \cdot 3$ & NS \\
\hline Urinary $N$ output $(\mathrm{g} / 7 \mathrm{~d})$ & 100 & 103 & 94 & 100 & $7 \cdot 4$ & NS \\
\hline $\mathrm{N}$ retention $(\mathrm{g} / 7 \mathrm{~d})$ & 122 & 121 & 110 & 115 & 6.7 & NS \\
\hline Apparent BV & 0.55 & 0.54 & 0.54 & 0.54 & $0 \cdot 033$ & NS \\
\hline
\end{tabular}

NS, not significant; FCR, food conversion ratio (DM intake $\div$ live-weight gain); BV, biological value ( $\mathrm{N}$ retention $\div \mathrm{N}$ apparently absorbed).

* $P<0.05$.

$\dagger$ For details of diets, see Table 1.

Table 3. Outputs and digestibilities of dry matter $(D M)$ and gross energy by pigs fed on wheat-based diets containing graded levels of raw peas (Pisum sativum var. Sentinel) $\dagger$

(Means for five pigs per diet)

\begin{tabular}{|c|c|c|c|c|c|c|}
\hline & \multicolumn{4}{|c|}{ Peas in diet $(\mathrm{g} / \mathrm{kg})$} & \multirow{2}{*}{$\begin{array}{l}\mathrm{SE} \text { of } \\
\text { mean }\end{array}$} & \multirow{2}{*}{$\begin{array}{l}\text { Statistical significance of } \\
\text { linear effect of dietary peas } \\
\text { inclusion rate }\end{array}$} \\
\hline & 0 & 100 & 200 & 300 & & \\
\hline $\begin{array}{l}\text { Faecal output } \\
\text { (g/7 d })\end{array}$ & 2402 & 2597 & 2818 & 2895 & 191.8 & NS \\
\hline $\begin{array}{l}\text { Faecal DM } \\
\text { (g/kg wet wt) }\end{array}$ & 336 & 354 & 317 & 330 & $20 \cdot 9$ & NS \\
\hline $\begin{array}{l}\text { Faecal DM } \\
\text { output }(g / 7 d)\end{array}$ & 873 & 884 & 935 & 946 & $75 \cdot 6$ & NS \\
\hline $\begin{array}{l}\text { Apparent DM } \\
\text { digestibility }\end{array}$ & 0.90 & $0 \cdot 90$ & $0 \cdot 89$ & 0.89 & 0.008 & NS \\
\hline $\begin{array}{l}\text { GE intake } \\
(\mathrm{MJ} / 7 \mathrm{~d})\end{array}$ & 162 & 171 & 153 & 170 & $2 \cdot 1$ & NS \\
\hline $\begin{array}{l}\text { Faecal GE } \\
(\mathrm{MJ} / \mathrm{kg} \mathrm{DM})\end{array}$ & 17.8 & $18 \cdot 7$ & $19 \cdot 6$ & $20 \cdot 8$ & 0.68 & $* *$ \\
\hline $\begin{array}{l}\text { Faecal GE } \\
\text { output }(\mathrm{MJ} / 7 \mathrm{~d})\end{array}$ & $15 \cdot 5$ & $16 \cdot 5$ & $18 \cdot 2$ & $19 \cdot 4$ & $1 \cdot 22$ & $*$ \\
\hline $\begin{array}{l}\text { Apparent GE } \\
\text { digestibility }\end{array}$ & 0.90 & 0.90 & $0 \cdot 88$ & 0.88 & $0 \cdot 007$ & $*$ \\
\hline $\begin{array}{l}\text { Urinary GE } \\
\text { output }(\mathrm{MJ} / 7 \mathrm{~d})\end{array}$ & $5 \cdot 3$ & $5 \cdot 3$ & $4 \cdot 9$ & $4 \cdot 9$ & $0 \cdot 27$ & NS \\
\hline
\end{tabular}

GE, gross energy; NS, not significant.

$* P<0.05, * * P<0.01$.

$\dagger$ For details of diets, see Table 1.

diet. Estimates of apparent digestibility for mannose were associated with relatively high $\mathrm{SE}$, probably because of the difficulty in measuring the small concentrations present in diets and faeces.

Since wheat and peas were the only significant sources of NSP in the diets, use of MLR 
Table 4. Apparent digestibilities of non-starch polysaccharides and constituents in pigs fed on wheat-based diets containing graded levels of raw peas (Pisum sativum var. Sentinel) $\dagger$

(Means for five pigs per diet)

\begin{tabular}{|c|c|c|c|c|c|c|}
\hline & \multicolumn{4}{|c|}{ Peas in diet $(\mathrm{g} / \mathrm{kg})$} & \multirow{2}{*}{$\begin{array}{l}\text { SE of } \\
\text { mean }\end{array}$} & \multirow{2}{*}{$\begin{array}{l}\text { Statistical significance of } \\
\text { linear effect of dietary peas } \\
\text { inclusion rate }\end{array}$} \\
\hline & 0 & 100 & 200 & 300 & & \\
\hline Total NSP & 0.65 & $0 \cdot 70$ & 0.71 & 0.75 & $0 \cdot 022$ & $*$ \\
\hline $\mathrm{NCP}$ & 0.72 & 0.77 & $0 \cdot 79$ & $0 \cdot 82$ & $0 \cdot 013$ & $* * *$ \\
\hline Cellulose & 0.34 & $0 \cdot 48$ & $0 \cdot 47$ & $0 \cdot 54$ & $0 \cdot 064$ & NS \\
\hline Arabinose & 0.60 & 0.73 & $0 \cdot 78$ & 0.87 & 0.019 & $* * *$ \\
\hline Xylose & 0.76 & 0.78 & $0 \cdot 78$ & $0 \cdot 80$ & $0 \cdot 018$ & NS \\
\hline Mannose & 0.46 & 0.61 & 0.55 & 0.57 & $0 \cdot 100$ & NS \\
\hline Galactose & $0 \cdot 33$ & $0 \cdot 71$ & $0 \cdot 74$ & $0 \cdot 79$ & $0 \cdot 022$ & $* * *$ \\
\hline Glucose & 0.60 & $0 \cdot 64$ & $0 \cdot 61$ & 0.68 & $0 \cdot 040$ & NS \\
\hline Uronic acidsț & 0.65 & 0.87 & $0-85$ & $0 \cdot 86$ & $0 \cdot 019$ & $* * *$ \\
\hline
\end{tabular}

NSP, non-starch polysaccharides; NCP, non-cellulosic polysaccharides; NS, not significant.

* $P<0.05, * * * P<0.001$.

$\uparrow$ For details of diets, see Table 1.

$\ddagger$ Responses for galactose and uronic acids contained significant non-linear components.

procedures allowed the derivation of separate estimates of digestibility for two foods. In addition, MLR model 1 tested the possibility that the presence of peas in the diet could influence the apparent digestibility of NSP (or its constituents) in wheat with the extent of this influence estimated as the parameter, $\alpha_{3}$ (Table 5). The latter was very small and not statistically significant for total NSP, NCP and most individual constituents of NSP, with the exceptions of galactose and uronic acids where highly significant $(P<0.001)$ negative values for $\alpha_{3}$ were obtained. These negative $\alpha_{3}$ values indicate that the estimated digestibility of wheat galactose and uronic acids were greater when peas were present in the diet. Apparent digestibilities for wheat NSP (and its constituents) estimated by MLR models 1 and 2 were similar and, as expected, close to those for the basal (zero peas) diet. Peas NSP were considerably more digestible than that of wheat with apparent digestibility of the NCP fraction not significantly different from unity. For both foods, the cellulose fraction had the lowest digestibility. Both MLR models provided very satisfactory descriptions of the relationship between intake and output of NSP and its constituents in these mixed diets, with $R^{2}$ greater than 0.92 for all components except mannose $\left(R^{2} 0.86\right)$. Oligosaccharides were not detected in faeces from pigs given the $300 \mathrm{~g}$ peas $/ \mathrm{kg}$ diet; other diet groups were not examined.

\section{Consequences of large intestinal fermentation}

As an index of large bowel (LB) bacterial biomass production, faecal DAPA was measured (Table 6). Faecal DAPA when expressed either as a proportion of faecal DM or crude protein, increased in a significant $(P<0.05)$ linear fashion with increasing peas inclusion rate. Similar increases were observed in faecal DAPA output but were not statistically significant given the relatively large between-animal variation. Part of this variation was due to differences in food intake (food provided was based on a fixed proportion of bodyweight daily) and when this was removed by expressing DAPA output per $\mathrm{kg}$ food DM intake, a highly significant $(P<0 \cdot 01)$ linear increase with increasing peas consumption became apparent (Table 6).

Blood glucose concentrations were consistently lower for pigs fed on peas than for those given the basal (zero peas) diet but this was not statistically significant (Table 7). All three 
Table 5. Apparent digestibilities, estimated by multiple linear regression $(M L R)^{*}$, for nonstarch polysaccharides (NSP) of wheat and raw peas (Pisum sativum var. Sentinel) when fed in mixed diets to growing pigs

(Estimates were derived using individual values for all twenty pigs; mean values with their standard errors)

\begin{tabular}{|c|c|c|c|c|c|c|c|}
\hline & \multicolumn{2}{|c|}{ Wheat } & \multicolumn{2}{|c|}{ Peas } & \multicolumn{2}{|c|}{$\alpha_{3}$} & \multirow[b]{2}{*}{$R^{2}$} \\
\hline & Mean & $\mathrm{SE}$ & Mean & $\mathrm{SE}$ & Mean & $\mathrm{SE}$ & \\
\hline \multicolumn{8}{|l|}{ MLR model 1} \\
\hline NSP & 0.65 & 0.034 & 0.85 & 0.080 & $0 \cdot 00 \mathrm{I}$ & 0.061 & 0.97 \\
\hline $\mathrm{NCP}$ & 0.72 & 0.081 & 1.01 & 0.080 & -0.003 & 0.035 & 0.98 \\
\hline Cellulose & 0.34 & $0 \cdot 124$ & 0.53 & 0.052 & -0.074 & 0.191 & 0.94 \\
\hline Arabinose & $0 \cdot 60$ & $0 \cdot 027$ & 1.05 & 0.056 & 0.010 & 0.052 & 0.98 \\
\hline Xylose & $0 \cdot 76$ & 0.021 & 1.07 & $0 \cdot 263$ & 0.008 & 0.040 & $0 \cdot 97$ \\
\hline Mannose & 0.44 & $0 \cdot 109$ & 0.44 & $0 \cdot 384$ & $-0 \cdot 194$ & $0 \cdot 199$ & 0.86 \\
\hline Galactose & 0.27 & $0 \cdot 055$ & 0.90 & 0.046 & -0.321 & 0.078 & 0.97 \\
\hline Glucose & $0 \cdot 60$ & $0 \cdot 070$ & $0 \cdot 72$ & $0 \cdot 120$ & 0.021 & $0 \cdot 142$ & 0.94 \\
\hline Uronic acids & $0 \cdot 66$ & $0 \cdot 044$ & 0.83 & 0.051 & -0.215 & 0.053 & 0.96 \\
\hline \multicolumn{8}{|l|}{ MLR model 2} \\
\hline NSP & 0.65 & $0 \cdot 027$ & 0.84 & 0.046 & & & 0.97 \\
\hline NCP & 0.72 & 0.015 & 1.02 & $0 \cdot 046$ & & & $0 \cdot 98$ \\
\hline Cellulose & $0-37$ & $0 \cdot 092$ & $0 \cdot 54$ & 0.044 & & & 0.94 \\
\hline Arabinose & $0 \cdot 60$ & 0.022 & 1.04 & 0.032 & & & 0.98 \\
\hline Xylose & $0 \cdot 76$ & $0 \cdot 017$ & $1 \cdot 03$ & $0 \cdot 150$ & & & 0.97 \\
\hline Mannose & $0 \cdot 50$ & 0.091 & 0.72 & $0 \cdot 241$ & & & $0 \cdot 86$ \\
\hline Galactose & 0.43 & 0.054 & 1.02 & $0 \cdot 048$ & & & 0.95 \\
\hline Glucose & 0.59 & $0 \cdot 059$ & 0.71 & 0.068 & & & $0 \cdot 94$ \\
\hline Uronic acids & 0.81 & 0.033 & 0.94 & 0.060 & & & $0 \cdot 92$ \\
\hline
\end{tabular}

$\alpha_{3}$, Additional effect of presence of peas on indigestibility of NSP fraction in wheat; NCP, non-cellulosic polysaccharides.

* For details of MLR models I and 2, see pp. 261-262.

Table 6. Faecal concentration and output of $\alpha, \epsilon$-diaminopimelic acid (DAPA) in pigs fed on wheat-based diets containing graded levels of raw peas (Pisum sativum var. Sentinel) $†$

(Mcans for five pigs per diet)

\begin{tabular}{|c|c|c|c|c|c|c|}
\hline & \multicolumn{4}{|c|}{ Peas in diet $(\mathrm{g} / \mathrm{kg})$} & \multirow{2}{*}{$\begin{array}{l}\text { SE of } \\
\text { mean }\end{array}$} & \multirow{2}{*}{$\begin{array}{l}\text { Statistical significance of } \\
\text { linear effect of dietary peas } \\
\text { inclusion rate }\end{array}$} \\
\hline & 0 & 100 & 200 & 300 & & \\
\hline $\begin{array}{c}\text { Faecal DAPA } \\
(\mathrm{mg} / \mathrm{g} \mathrm{DM})\end{array}$ & $1 \cdot 3$ & $1 \cdot 3$ & 1.6 & $1 \cdot 7$ & $0 \cdot 13$ & * \\
\hline $\begin{array}{l}\text { Faecal DAPA } \\
(\mathrm{g} / 16 \mathrm{~g} \text { faecal } \mathrm{N})\end{array}$ & 0.57 & $0 \cdot 49$ & 0.68 & 0.75 & 0.063 & * \\
\hline $\begin{array}{l}\text { Faecal DAPA } \\
\text { output }(g / 7 \mathrm{~d})\end{array}$ & $1 \cdot 2$ & $1 \cdot 1$ & 1.5 & 1.6 & 0.20 & NS \\
\hline $\begin{array}{l}\text { Faecal DAPA } \\
\text { output }(\mathrm{g} / \mathrm{kg} \\
\text { DM intake) }\end{array}$ & 0.12 & $0 \cdot 10$ & 0.16 & $0 \cdot 18$ & 0.016 & $* *$ \\
\hline
\end{tabular}

NS, not significant; DM, dry matter.

* $P<0.05,{ }^{* *} P<0.01$.

$\dagger$ For details of diets, see Table 1 . 
Table 7. Concentrations of glucose ( $m M$ ) and of volatile fatty acids $(\mu M)$ in peripheral blood from pigs fed on wheat-based diets containing graded levels of raw peas (Pisum sativum var. Sentinel $\dagger$

(Means for five pigs per diet)

\begin{tabular}{|c|c|c|c|c|c|c|}
\hline & \multicolumn{4}{|c|}{ Peas in diet $(\mathrm{g} / \mathrm{kg})$} & \multirow{2}{*}{$\begin{array}{l}\text { SE of } \\
\text { mean }\end{array}$} & \multirow{2}{*}{$\begin{array}{l}\text { Statistical significance of } \\
\text { linear effect of dietary peas } \\
\text { inclusion rate }\end{array}$} \\
\hline & 0 & 100 & 200 & 300 & & \\
\hline Glucose & $4 \cdot 7$ & $4 \cdot 1$ & $4 \cdot 0$ & $4 \cdot 1$ & $0 \cdot 28$ & NS \\
\hline Acetate & 291 & 302 & 385 & 409 & $34 \cdot 8$ & $*$ \\
\hline Propionate & 17 & 14 & 27 & 25 & 3.8 & * \\
\hline Butyrate & 9 & 10 & 13 & 24 & $4 \cdot 3$ & $*$ \\
\hline Total VFA & 317 & 326 & 425 & 459 & $39 \cdot 3$ & $* *$ \\
\hline
\end{tabular}

VFA, volatile fatty acids; NS, not significant.

$* P<0 \cdot 05, * * P<0 \cdot 01$.

$\uparrow$ For details of diets, see pp. 260-261.

major VFA (acetate, propionate and butyrate) produced by LB fermentation could be detected in peripheral blood, with acetate accounting for 0.89-0.93 of the total on a molar basis. Increasing peas in the diet resulted in linear increases in blood concentration of each VFA, with butyrate showing the largest proportional increase $(2 \cdot 5$-fold $)$.

\section{DISCUSSION}

Although there is now no doubt that plant cell wall polysaccharides in many foods can be extensively digested by omnivorous animals including man (Cummings, 1981), and that this occurs largely by fermentation within the LB, the factors which influence the extent of fermentation of NSP for a given food in a particular animal are poorly understood. There is no clear evidence of between-species differences in the rate of degradation, but it is probable that the time available for fermentation (transit time, TT) will have a major influence on NSP digestibility (Stephen et al. 1987). The shorter TT in the chicken LB compared with that in the rat may explain the less extensive fermentation of peas NSP by cockerels (Longstaff \& McNab, 1987) than by rats (Goodlad \& Mathers, 1990). TT in the pig LB is considerably longer (1-5 d; Luckey et al. 1979; Mroz et al. 1986) than that in the rat (0.5-1 d; Goodlad \& Mathers, 1990; Mathers et al. 1990) so it might be expected that pigs would ferment NSP more effectively than would rats. This was examined in the present study.

\section{Faecal composition}

Whilst there were no significant effects of diet on faecal output of wet or dry matter, both tended to increase when feeding peas. Faeces from pigs fed on peas tended to have lower DM content but had significantly $(P<0.05)$ greater concentrations of energy and of DAPA in that DM. The higher faecal concentration and output of DAPA suggests strongly, but does not prove, that there was greater bacterial biomass production with the peas-containing diets. The possibility that diet may alter the DAPA concentration in bacterial cells (Czerkawski, 1976) means that it is not possible to assume constant proportionality between faecal DAPA outputs and faecal bacterial biomass.

The increased faecal energy density for pigs fed on peas was unexpected and suggests a higher concentration of lipid was present. This extra lipid may have been derived from several sources including unabsorbed dietary fat, endogenous lipid and lipid synthesized by 
LB bacteria. Additional maize oil was added to the peas-containing diets (Table 1) but this is a highly digestible product and is unlikely to affect faecal fat concentrations in the amounts used. More likely is the possibility that peas reduced the ileal absorption of bile salts and other steroids and increased their output in faeces. Several dietary fibre sources including pectin and guar gum have this effect (Kay \& Truswell, 1977; Miettinen \& Tarpila, 1977; Shutler et al. 1987) and the blood-cholesterol-lowering properties of legume-rich diets (Mathur et al. 1968; Shutler et al. 1989) may be due, in part, to this steroid-binding property. Gut anaerobic bacteria are relatively rich in lipid $(100-200 \mathrm{~g} / \mathrm{kg} \mathrm{DM}$; Czerkawski, 1976) and if feeding peas resulted in greater bacterial biomass production as suggested by the DAPA results, a greater concentration of bacterial lipid in faeces would also be expected, resulting in the observed increase in faecal energy density.

\section{Digestion of NSP}

Including peas in the diet increased dietary NSP concentration by up to twofold and was associated with marked increases in the apparent digestibility of whole-diet NSP which suggested that the peas NSP were considerably more digestible than those of wheat (Table 4). The use of MLR procedures allowed calculation of separate estimates of apparent digestibility for wheat and for peas NSP and also tested the possibility that the presence of one dietary component (peas) could influence the apparent digestibility of the other (wheat), i.e. MLR model 1 tested for associative effects (Mitchell, 1964). For NSP and its major components, there was little evidence of any associative effect between wheat and peas (Table 5). The observation that $\alpha_{3}$ was significant and negative for galactose and uronic acids implies that the digestibility of these components in wheat was increased by having peas in the diet. Whilst this possibility is of some interest, it is unlikely to be of nutritional significance given the small contribution made by these components to the total NSP fraction. The simpler MLR model 2 provided a very good description of the relationships between NSP (and each of its components) output in faeces and intake from wheat and peas.

The apparent digestibility of wheat NSP $(0.65)$ was similar to those $(0.61$ and 0.65$)$ reported for barley (Fadel et al. 1988), higher than that $(0.48)$ observed for a basal mixedcereal diet based on wheat, barley and oats (Graham et al. 1986) and midway between estimates of 0.52 and 0.78 reported for another basal diet containing wheat, barley and soya-bean meal (Longland \& Low, 1989). All these estimates were obtained in pigs. In contrast, poultry appear to digest wheat NSP less effectively with coefficients of digestibility of 0.30-0.46 reported by Longstaff \& McNab (1986) whilst rats digested 0.56 of the NSP in wholemeal bread (Key \& Mathers, 1990).

Table 8 gives a comparison of estimates of the apparent digestibility of raw peas NSP and its constituent sugars for chickens (Longstaff \& McNab, 1987), rats (Goodlad \& Mathers, 1990) and pigs (present study). The major between-species difference is the markedly lower digestibility by poultry. It is possible that this difference is due, in part, to the experimental protocol used by Longstaff \& McNab (1987) who starved their birds for $48 \mathrm{~h}$ before tubefeeding a single meal of peas. Starvation for 24 or $48 \mathrm{~h}$ greatly reduced the weight of rat caecal contents and the concentrations of VFA in that organ (Illman et al. 1986) and may reduce the LB capacity for NSP fermentation in the immediate re-feeding period. However, other work has shown very poor digestibility of NSP from white lupin (Lupinus albus L.) cotyledon by adult cockerels (Carré \& Leclercq, 1985) so that the relatively low digestibility of peas NSP observed by Longstaff \& McNab (1987) may illustrate a true species effect.

Apparent digestibilities of NSP and of NCP were slightly greater by pigs than by rats but the rats seemed to digest cellulose better than did the pigs. It is not clear to what extent these differences are real between-species differences or confounded by possible differences in the 
Table 8. Comparison of the apparent digestibility of raw peas non-starch polysaccharides (NSP) and its constituent sugars by chickens, rats and pigs

\begin{tabular}{|c|c|c|c|}
\hline $\begin{array}{l}\text { Source ... } \\
\text { Species ... }\end{array}$ & $\begin{array}{c}\text { Longstaff \& McNab } \\
\text { (1987) } \\
\text { Chickens* }\end{array}$ & $\begin{array}{c}\text { Goodlad \& Mathers } \\
(1990) \\
\text { Rats }\end{array}$ & $\begin{array}{c}\text { Present study } \\
\text { Pigs }\end{array}$ \\
\hline NSP & $0.38 \dagger$ & 0.79 & 0.84 \\
\hline NCP & - & 0.90 & 1.02 \\
\hline Cellulose & - & 0.68 & 0.54 \\
\hline Arabinose & 0.32 & 0.99 & 1.04 \\
\hline Xylose & 0.11 & 0.58 & 1.03 \\
\hline Mannose & 0.48 & 0.84 & 0.72 \\
\hline Galactose & 0.52 & 0.89 & 1.02 \\
\hline Glucose & 0.47 & 0.74 & $0 \cdot 7 \mathrm{I}$ \\
\hline Uronic acids & - & 0.78 & 0.94 \\
\hline
\end{tabular}

NCP, non-cellulosic polysaccharides.

* Mean for two experiments.

$\dagger$ Does not include uronic acids.

susceptibility to fermentation of the two peas samples. We are not aware of any systematic study of the digestion of NSP from different pea varieties. Although different varieties of wheat appeared to differ in NSP digestibility by poultry, none of the varietal differences was statistically significant (Longstaff \& McNab, 1986).

\section{Consequences of large intestinal fermentation}

Clearly pigs are able to digest most of the cell wall material in raw peas. Whilst the intestinal site of digestion of these carbohydrates was not examined in the present study and it is recognized that a portion of this material may be digested before the end of the ileum (Millard \& Chesson, 1984; Graham et al. 1986; Fadel et al. 1988), it is reasonable to assume that the majority of this carbohydrate was fermented in the LB, with VFA as the major energy-containing end-products. These VFA are readily absorbed (McNeil et al. 1978; Ruppin et al. 1980) and passed via the portal vein to the liver. Stimulation of LB fermentation by feeding lactose to weaned pigs has been shown to raise portal VFA concentrations (Giusi-Perier et al. 1989). Including peas in semi-purified diets for rats resulted in higher concentrations of acetate, propionate and butyrate in portal blood but only acetate was detected in peripheral blood and increased with increasing peas consumption (Goodlad \& Mathers, 1990). This efficient removal of the $C_{3}$ and $C_{4}$ VFA was expected given the relatively high activities of liver propionyl- and butyryl-CoA synthetases (EC 6.2.1.17 and EC 6.2.1.2 respectively) (Aas, 1971; Ash \& Baird, 1973). Whilst acetate was the major VFA in jugular blood in the present study, propionate and butyrate were also detected and all three VFA increased with increasing dietary peas inclusion rate. Propionate and butyrate were also detected in blood collected from the ear vein of pregnant sows and increased (significantly so for propionate) when additional oat hulls were eaten (Mroz et al. 1986). Taken together, the results of these two studies suggest that the pig liver may not be as efficient as that of the rat in removing absorbed VFA so raising the possibility that these metabolites will reach peripheral tissues where their fate and effects are uncertain.

The non-significant reduction in blood glucose concentration in peas-fed pigs may be a consequence of a reduced rate of glucose absorption from the slowly digested pea starch (Fleming \& Vose, 1979; Snow \& O'Dea, 1981; Longstaff \& McNab, 1987) compared with the sucrose which it replaced in the diet and is in line with reports of better glucose tolerance with legume-containing diets (Simpson et al. 1981; Tappy et al. 1986). 
J.S.G. was in receipt of a SERC CASE award in co-operation with Unilever Research, Colworth Laboratory, Bedford and the authors thank R. Mawson and P. J. Evans for their interest and assistance. Dr M. Ellis is thanked for access to the pig metabolism facility and P. Briggs for assistance with the animals.

\section{REFERENCES}

Aas, M. (1971). Organ and subcellular distribution of fatty acid activating enzymes in the rat. Biochimica et Biophysica Acta 231, 32-47.

Ash, R. \& Baird, G. D. (1973). Activation of volatile fatty acids in bovine liver and rumen epithelium. Evidence for control by autoregulation. Biochemical Journal 136, 311-319.

Carré, B. \& Leclercq, B. (1985). Digestion of polysaccharides, protein and lipids by adult cockerels fed on diets containing a pectic cell-wall material from white lupin (Lupinus albus L.) cotyledon. British Journal of Nutrition 54, 669-680.

Cummings, J. H. (198I). Dietary fibre. British Medical Bulletin 37, 65-70.

Cummings, J. H. \& Englyst, H. N. (1987). Fermentation in the human large intestine and the available substrates. American Journal of Clinical Nutrition 45, 1243-1245.

Czerkawski, J. W. (1976). Chemical composition of microbial matter in the rumen. Journal of the Science of Food and Agriculture 27, 621-632.

Englyst, H. N. \& Cummings, J. H. (1984). Simplified method for the measurement of total non-starch polysaccharides by gas-liquid chromatography of constituent sugars as alditol acetates. Analyst 109, 937-942.

Fadel, J. G., Newman, C. W., Newman, R. K. \& Graham, H. (1988). Effects of extrusion cooking of barley on ileal and faecal digestibilities of dietary components in pigs. Canadian Journal of Animal Science 68, 891-897.

Fleming, S. E. \& Vose, J. R. (1979). Digestibility of raw and cooked starches from legume seeds using the laboratory rat. Journal of Nutrition 109, 2067-2075.

Giusi-Perier, A., Fiszlewicz, M. \& Rérat, A. (1989). Influence of diet composition on intestinal volatile fatty acid and nutrient absorption in unanaesthetized pigs. Journal of Animal Science 67, 386-402.

Goodlad, J. S. \& Mathers, J. C. (1990). Large bowel fermentation in rats given diets containing raw peas (Pisum sativum). British Journal of Nutrition 64, 569-587.

Graham, H., Hesselman, K. \& Aman, P. (1986). The influence of wheat bran and sugar-beet pulp on the digestibility of dietary components in a cereal-based pig diet. Journal of Nutrition 116, 242-251.

Illman, R. J., Topping, D. L. \& Trimble, R. P. (1986). Effects of food restriction and starvation-refeeding on volatile fatty acid concentrations in the rat. Journal of Nutrition 116, 1694-1700.

Kay, R. M. \& Truswell, A. S. (1977). Effects of citrus pectin on blood lipids and faecal steroid excretion in man. American Journal of Clinical Nutrition 30, 171-175.

Key, F. B. \& Mathers, J. C. (1990). Estimation of the digestibilities of NSP for wholemeal bread and haricot beans fed in mixed diets. In Dietary Fibre: Chemical and Biological Aspects, pp. 254 258 [D. A. T. Southgate, K. Waldron, I. T. Johnson and G. R. Fenwick, editors]. Cambridge: Royal Society of Chemistry.

Longland, A. C. \& Low, A. G. (1989). Digestion of diets containing molassed or plain sugar-beet pulp by growing pigs. Animal Feed Science and Technology 23, 67-78.

Longstaff, M. \& McNab, J. M. (1986). Influence of site and variety on starch, hemicellulose and cellulose composition of wheats and their digestibilities by adult cockerels. British Poultry Science 27, 435-449.

Longstaff, M. \& McNab, J. M. (1987). Digestion of starch and fibre carbohydrates in peas by adult cockerels. British Poultry Science 28, 261-285.

Luckey, T. D., Hartman, R., Kay, M. \& Hutcheson, D. (1979). Alimentary kinetics of pigs fed three meals daily. Nutrition Reports International 19, 135-140.

MeNeil, N. I., Cummings, J. H. \& James, W. P. T. (1978). SCFA absorption by the human large intestine. Gut $19,819-822$.

Mathers, J. C., Fernandez, F., Hill, M. J., McCarthy, P. T., Shearer, M. J. \& Oxley, A. (1990). Dietary modification of potential vitamin K supply from enteric bacterial menaquinones in rats. British Journal of Nutrition 63, 639-652.

Mathur, K. S., Khan, M. A. \& Sharma, R. D. (1968). Hypocholesterolaemic effect of Bengal gram: a long-term study in man. British Medical Journal i, 30-31.

Miettinen, T. A. \& Tarpila, S. (1977). Effect of pectin on serum cholesterol, fecal bile acids and biliary lipids in normolipidemic and hyperlipidemic individuals. Clinica Chimica Acta 79, 471-477.

Millard, P. \& Chesson, A. (1984). Modification to Swede (Brassica napus L.) anterior to the terminal ileum of pigs: some implications for the analysis of dietary fibre. British Journal of Nutrition 52, 583-594.

Mitchell, H. H. (1964). Comparative Nutrition of Man and Domestic Animals. New York: Academic Press.

Mroz, Z., Partridge, I. G., Mitchell, G. \& Keal, H. D. (1986). The effect of oat hulls, added to the basal ration for pregnant sows, on reproductive performance, apparent digestibility, rate of passage and plasma parameters. Journal of the Science of Food and Agriculture 37, 239-247.

Pomare, E. W., Branch, W. J. \& Cummings, J. H. (1985). Carbohydrate fermentation in the human colon and its relation to acetate concentrations in venous blood. Journal of Clinical Investigation 75, 1448-1454. 
Ruppin, H., Bar-Meir, S., Soergel, K. H. \& Schmitt, M. G. (1980). Absorption of SCFA by the colon. Gastroenterology 78, 1500-1507.

Shutler, S. M., Bircher, G. M., Tredger, J. A., Morgan, L. M., Walker, A. F. \& Low, A. G. (1989). The effect of daily baked bean (Phaseolus vulgaris) consumption on plasma lipid levels of young, normo-cholesterolaemic men. British Journal of Nutrition 61, 257-265.

Shutler, S. M., Walker, A. F. \& Low, A. G. (1987). The cholesterol-lowering effects of legumes. II : Effects of fibre, sterols, saponins and isoflavones. Human Nutrition: Food Sciences and Nutrition 41F, 87-102.

Simpson, H. C. R., Lousley, S., Geekie, M., Simpson, R. W., Carter, R. D., Hockaday, T. D. R. \& Mann, J. I. (1981). A high carbohydrate leguminous fibre diet improves all aspects of diabetic control. Lancet i, 1-5.

Snow, P. \& O'Dea, K. (1981). Factors affecting the rate of hydrolysis of starch in food. American Journal of Clinical Nutrition 34, 2721-2727.

Stephen, A. M., Wiggins, H. S. \& Cummings, J. H. (1987). Effect of changing transit time on colonic microbial metabolism in man. Gut 28, 601-609.

Tappy, L., Würsch, P., Randin, J. P., Felber, J. P. \& Jéquier, E. (1986). Metabolic effect of pre-cooked instant preparations of bean and potato in normal and diabetic subjects. American Journal of Clinical Nutrition 43, 30-36.

van Dokkum, W., Pikaar, N. A. \& Thissen, J. T. N. M. (1983). Physiological effects of fibre-rich types of bread. 2. Dietary fibre from bread: digestibility by the intestinal microflora and water-holding capacity in the colon of human subjects. British Journal of Nutrition 50, 61--74.

Würsch, P., Del Vedovo, S. \& Koellreutter, B. (1986). Cell structure and starch nature as key determinants of the digestion rate of starch in legumes. American Journal of Clinical Nutrition 43, 25-29. 